\title{
Opportunity for Comparison
}

\section{Im letzten Jahr wurde auch in Japan ein Ranking von Umweltberichten durchge- führt. Die Anlehnung an die Methode des IÖW/ future-Rankings in Deutschland ermöglicht aufschlussreiche Vergleiche.}

$\mathrm{L}$ Von Naobiko Ando ast year a ranking of Japanese environmental reports was carried out by Kyoto Seika University and Kino Eco, an environmental NGO (1). The Japanese Ranking was based on the same criteria and methodology used in the German ranking of environmental reports developed and applied by IÖW and future e.V. (2).

In the Japanese ranking 148 corporations, co-ops and local governments participated and submitted voluntarily a year 2000 version of their environmental report. Thus one third of a total of almost 430 organizations that issued environmental reports in Japan during 2000/2001 were included. Most of the reports, however, were from individual companies of varying size. For major companies, many of the reports were made up from a corporate group and included a report for each site.

While the grading and ranking was carried out in accordance with the criteria of the German Ranking, only the names of the top 60 corporations have been published on the website of Kino Eco. The full results in each ranking criteria were only published for the top 20 corporations.

The best report is published by Kirin Brewery. Among the top ten are several internationally known companies such as Nissan (rank 3), Konica (rank 6), Canon (rank 7) and Seiko (rank 10) (see table 1). The average of the top 20 corporations was 241 points and the average of the top 60 corporations was 212 points.

\section{Results in Comparison}

Because the German and the Japanese Ranking are based on the same criteria it is possible to compare the results. However, some differences need to be considered: For example, the Japanese ranking considers a much larger number of reports than the German one. Furthermore the German Ranking considers only top 100 companies in industry, plus some large companies in finance and trade whereas in Japan reports from co-ops and local governments also participated.
Nevertheless we carried out some comparisons: Obviously there is a difference in total points, such as the Japanese top total (299,95 points) was 118 points lower than the top German total of 418 points and the average of the top 60 Japanese corporations was 73 points less than the 285 point average for Germany. The higher scores in Germany might be the result of a longer experience in environmental reporting in this country.

of the top 20 ranked organizations in Japan, 50 per cent were from the electric industry, while transportation (automobile) and food were 10 per cent each; whereas in Germany, it was well balanced with automobiles, electronics/information technology and chemicals all being 15 per cent each. This shows a tendency that industries which do a lot of exporting and industries that have a direct connection with consumers such as food tend to submit superior reports.

Looking at single ranking criteria there are also some specific differences: Many of the reports in Japan lack a concrete commitment regarding their environmental policy. Furthermore material and energy flows in general, and particularly on company or site level, are rarely mentioned. None of them used input output balances which are common in German Reports. This concept is quite unfamiliar

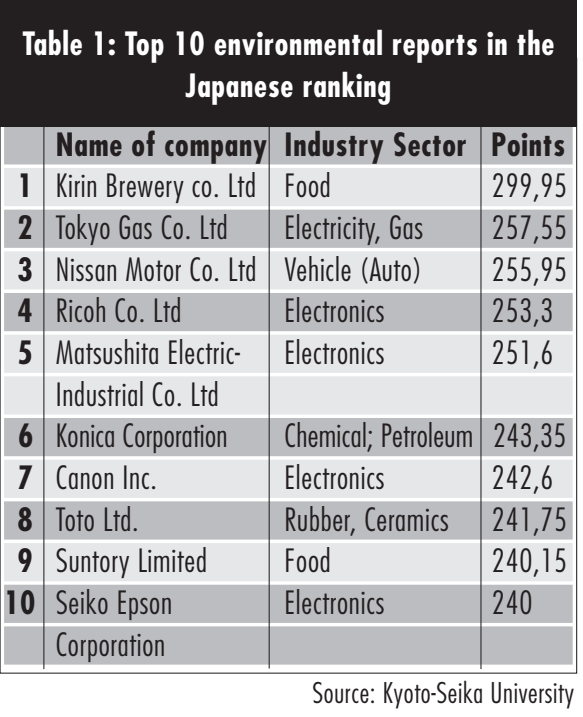

in Japan, and it is not included in the environmental reporting guidelines issued by the Ministry of Environment.

Summing up, a significant difference between Germany and Japan was observed in this ranking. One of the causes is a difference in the guidelines to be followed. Further interesting results of the analysis are:

- Only two companies mentioned how ,sustainable development" should be carried out.

- In terms of use of the internet, many companies put their environmental report on their web site. Only a few companies, however, allow access to information beyond the report in the booklet, and there is no systematic usage.

- For financial information, the Ministry of the Environment has published the Environmental Accounting Guidebook II (3). Therefore a significant number of corporations reported on their budget for environmental measures and investment. However, almost none of them mentioned the effects, and in particular, the effect on market development.

- Almost all the reports by corporations in the automobile and electric industry discussed the environmental aspects of their products, but they focused only on energy consumption and carbon dioxide emissions. A rather large number of corporations in the automobile and electric industry indicated a systematic product development policy; other industries only mentioned it topically. To date, an examination of the publications and a variety of awards for 2001 has been completed. There are many organizations that employ international standards such as the Global Reporting Initiative guideline. Overall, the results have been gradually improving in both quality and quantity.

\section{References}

(1) For further information see www.kyoto-seika.ac.jp/ kinoeco/ranking/ (in Japanese)

(2) See www.ranking-umweltberichte.de or Fichter, K./ Clausen, J./ Loew, T.: Non-reporters werden zur Minderheit. In: Ökologisches Wirtschaften, №. 5/2000, pp. 5-6.

(3) On this topic see Kokubu, K: Environmental Cost Accounting in Japan. In: Ökologisches Wirtschaften, No. 6/01, pp. 12-13.

\section{Der Autor}

Naohiko Ando ist Lehrbeauftragter an der Kyoto-Seika University in Kyoto.

Kontakt: Kino Eco c/o Kyoto-Seika University, 137, Iwakura-Kino-machi, Sakyo-ku, Kyoto, Japan. Fax 0081-75-702-5253, E-mail: nando@owari.ne.jp 
(c) 20I0 Authors; licensee IÖW and oekom verlag. This is an article distributed under the terms of the Creative Commons Attribution Non-Commercial No Derivates License (http://creativecommons.org/licenses/by-nc-nd/3.o/), which permits unrestricted use, distribution, and reproduction in any medium, provided the original work is properly cited. 